\title{
Global vitamin D status and determinants of hypovitaminosis D
}

\author{
A. Mithal • D. A. Wahl • J.-P. Bonjour • P. Burckhardt • \\ B. Dawson-Hughes $\cdot$ J. A. Eisman • \\ G. El-Hajj Fuleihan • R. G. Josse • P. Lips • \\ J. Morales-Torres • \\ on behalf of the IOF Committee of Scientific Advisors \\ (CSA) Nutrition Working Group
}

Received: 10 February 2009 / Accepted: 20 April 2009/Published online: 19 June 2009

(C) International Osteoporosis Foundation and National Osteoporosis Foundation 2009

\begin{abstract}
Summary This review describes the vitamin D status in different regions of the world with the objective of understanding the scope of hypovitaminosis D and the factors related to its prevalence that may contribute to the pathogenesis of osteoporosis and fragility fractures.

Introduction Vitamin D status has been linked to the pathogenesis of hip fractures as well as other skeletal and non-skeletal disorders. The purpose of this review is to provide a global perspective of vitamin D status across
\end{abstract}

A. Mithal $(\bowtie)$

Indraprastha Apollo Hospitals,

Sarita Vihar, Delhi-Mathura Road,

110044 New Delhi, India

e-mail: ambrish.mithal@rediffmail.com

D. A. Wahl

International Osteoporosis Foundation,

9, Rue Juste Olivier,

1203 Nyon, Switzerland

B. Dawson-Hughes

Department of Agriculture Human Nutrition,

Research Center on Aging, Tufts University,

711 Washington Street,

Boston, MA 02111, USA

J.-P. Bonjour

Division of Bone Diseases,

Geneva Hospitals and Faculty of Medicine,

Rue Micheli-du-Crest 24,

1211 Geneva, Switzerland

P. Burckhardt

Association Suisse contre 1'Ostéoporose, Clinique Bois-Cerf,

Avenue d'Ouchy 31,

1006 Lausanne, Switzerland different regions of the world and to identify the common and significant determinants of hypovitaminosis D.

Methods Six regions of the world were reviewed-Asia, Europe, Middle East and Africa, Latin America, North America, and Oceania - through a survey of published literature.

Results The definition of vitamin D insufficiency and deficiency, as well as assay methodology for 25hydroxyvitamin $\mathrm{D}$ or $25(\mathrm{OH}) \mathrm{D}$, vary between studies. However, serum 25(OH)D levels below $75 \mathrm{nmol} / \mathrm{L}$ are

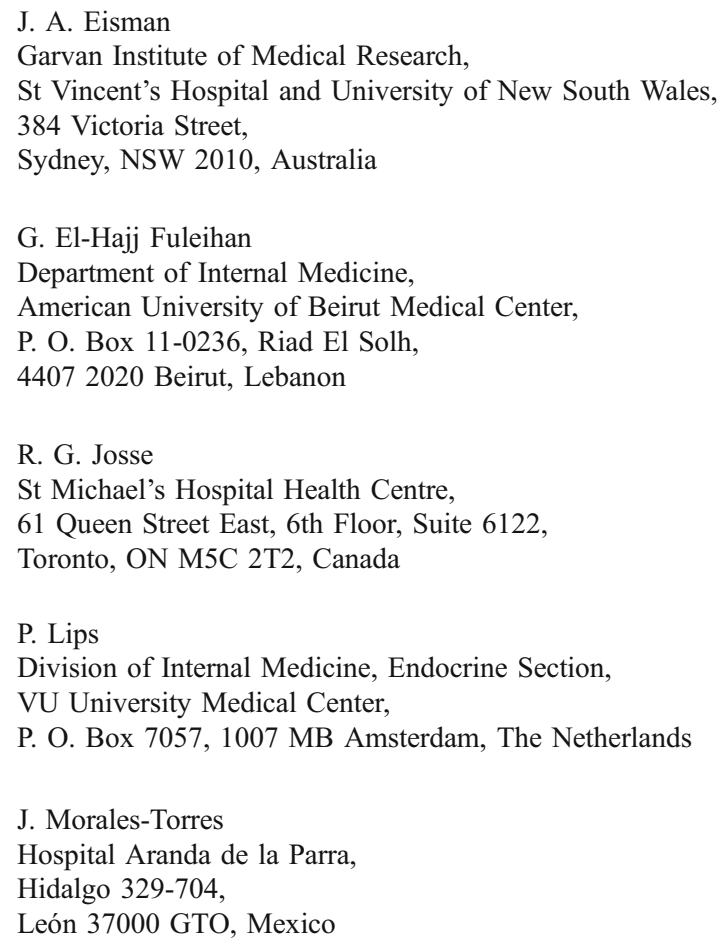


prevalent in every region studied whilst levels below $25 \mathrm{nmol} / \mathrm{L}$ are most common in regions such as South Asia and the Middle East. Older age, female sex, higher latitude, winter season, darker skin pigmentation, less sunlight exposure, dietary habits, and absence of vitamin $\mathrm{D}$ fortification are the main factors that are significantly associated with lower $25(\mathrm{OH}) \mathrm{D}$ levels.

Conclusion Reports from across the world indicate that hypovitaminosis D is widespread and is re-emerging as a major health problem globally.

Keywords Prevalence · Serum 25-hydroxyvitamin D . Vitamin D deficiency

\section{Introduction}

Vitamin D plays a primary physiological role in maintaining extracellular calcium ion levels in the human body. Extracellular calcium is vital for the functioning of many metabolic processes and neuromuscular activities. Vitamin $\mathrm{D}$ influences calcium levels primarily by controlling the absorption of calcium from the intestine, through direct effects on bone and also through its effects on parathyroid hormone (PTH) secretion $[1,2]$. Furthermore, vitamin D deficiency, resulting in decrease bone mineralisation, secondary hyperparathyroidism, and increased cortical bone loss, has been linked to the pathogenesis of osteoporosis and hip fractures [3, 4]. Vitamin D is acquired both through nutritional means (10-20\%) and by the cutaneous synthesis under the action of sunlight (80-90\%) [5]. Vitamin $\mathrm{D}_{3}$ or cholecalciferol, after formation in the skin, and vitamin $\mathrm{D}_{2}$ or $\mathrm{D}_{3}$, from dietary sources, undergo hydroxylation in the liver, resulting in formation of 25-hydroxyvitamin D or 25 $(\mathrm{OH}) \mathrm{D}$, the chief circulating form. $25(\mathrm{OH}) \mathrm{D}$ subsequently undergoes hydroxylation in the kidney under the influence of $1 \alpha$-hydroxylase enzyme to yield the biologically active, dihydroxylated form of vitamin $\mathrm{D}$, calcitriol or 1,25 $(\mathrm{OH})_{2} \mathrm{D}$, which acts through specific vitamin D receptors to regulate not only calcium metabolism, but also differentiation and division of various cell types. It has been suggested that in addition to its pivotal role in bone mineralisation, calcium homeostasis, and its related disorders, vitamin D may play a role in muscle strength $[6,7]$, pathogenesis of psoriasis [8], certain cancers [9, 10], multiple sclerosis (MS) [11], diabetes [12], and blood pressure [13], among other physiological and pathophysiological processes.

Determining vitamin D status of a population can be a challenging task. While $1,25(\mathrm{OH})_{2} \mathrm{D}$ is the biologically active, "hormonal" form of the vitamin, many health effects correlate better with circulating 25(OH)D levels. Indirect evidence suggests that this may be due to widespread (extrarenal) presence of the enzyme $1 \alpha$-hydroxylase, which leads to intracellular formation of $1,25(\mathrm{OH})_{2} \mathrm{D}$ in many target tissues, resulting in high local concentrations and cell or tissue specific effects [14]. Therefore, this report will focus only on $25(\mathrm{OH}) \mathrm{D}$ levels. However, methods for measuring $25(\mathrm{OH}) \mathrm{D}$ levels vary widely. Two commonly used assays presented up to $80 \%$ differences in vitamin D levels, especially at lower values [15]. Therefore, comparing vitamin D levels between studies is not reliable unless the same assay is used or the assays are appropriately cross-calibrated.

Earlier observational studies have measured serum 25 $(\mathrm{OH}) \mathrm{D}$ levels in healthy population cohorts to determine reference values for sufficient levels of vitamin D. However, these are known to be influenced by lifestyle and environmental characteristics and, therefore, may not be applied clinically and worldwide [2, 4]. Defining different levels of vitamin $\mathrm{D}$ according to health consequences rather than population means is the preferred method but has led to an ongoing debate about what constitutes "normal" or "optimal" 25(OH)D levels. Several criteria have been used to define sufficient 25(OH)D levels, including the level associated with optimal suppression of circulating PTH levels, greatest calcium absorption, highest bone mineral density (BMD), lowest rates of bone loss, falls, or fractures [16]. Hypovitaminosis D is the condition below this level where a population is insufficient or deficient in vitamin $\mathrm{D}$, depending on the severity of its health consequence. Clinical hypovitaminosis D is associated with rickets in infancy and osteomalacia in adults, which causes muscle weakness and contributes to falls and bone fractures. Defining categories of vitamin D insufficiency and deficiency will affect the prevention strategies employed in a clinical setting. These are oral vitamin D supplementation, increased exposure to UV light (especially sunlight), and a better dietary intake.

The aim of this report is to describe $25(\mathrm{OH}) \mathrm{D}$ levels in different population groups across the world and highlight what determinants influence vitamin D status. To provide a truly global perspective, six regions (Asia, Europe, Latin America, Middle East/Africa, North America, and Oceania) have been included, and the effect of age, gender, ethnicity, latitude, clothing, nutrition, skin pigmentation, cultural practises, living conditions, and physical activity on vitamin D status of these populations has been emphasised.

\section{Asia}

As early as the 1970 s, studies clearly showed that migrant populations from Asian countries, when exposed to higher latitudes, were unable to maintain optimal vitamin D levels [17-19]. Frank rickets and osteomalacia were not uncom- 
mon in these migrants. More recently, studies carried across different countries in South and Southeast Asia showed, with few exceptions, widespread prevalence of hypovitaminosis D in both sexes and all age groups of the population.

Several studies have demonstrated low serum vitamin 25 $(\mathrm{OH}) \mathrm{D}$ levels in populations across India [20-22]. In North India $\left(27^{\circ} \mathrm{N}\right), 96 \%$ of neonates [23], $91 \%$ of healthy school girls [24], 78\% of healthy hospital staff [20], and $84 \%$ of pregnant women [23] were found to have hypovitaminosis D. The criteria used for defining hypovitaminosis D in most of the studies was a serum 25(OH)D level below $50 \mathrm{nmol} / \mathrm{L}$.

A major concern is the high prevalence of hypovitaminosis D among pregnant women and children. Maternal serum 25 (OH)D levels correlated negatively with PTH levels and positively with cord blood 25(OH)D levels [23]. Seasonal variation in serum $25(\mathrm{OH}) \mathrm{D}$ levels, reflected as winter hypovitaminosis $\mathrm{D}$, has been demonstrated in several studies $[25,26]$. Air pollution probably also plays a role in large cities [27]. Hypovitaminosis D is equally prevalent among rural and urban subjects, [23] but in some studies, urban subjects are found to be more deficient [24, 28].

In South India $\left(13^{\circ} \mathrm{N}\right)$, hypovitaminosis $\mathrm{D}$ is equally prevalent among different population groups $[28,29]$. In a population-based study showing the inverse relationship between measured serum 25(OH)D levels and PTH levels, vitamin $\mathrm{D}$ levels were significantly higher in rural compared to urban subjects [30].

Similar data have been obtained from Pakistan, most disturbingly from infants [31, 32]. In Bangladesh $\left(24^{\circ} \mathrm{N}\right)$, hypovitaminosis D is common in women regardless of age, lifestyle, and clothing [33]. Prevalence of hypovitaminosis defined as 25(OH)D levels below $37.5 \mathrm{nmol} / \mathrm{L}$ was $38 \%$ in Bangladeshi women from high-income group and increased slightly to $50 \%$ in women from low income groups [34]. In Sri Lanka $\left(7^{\circ} \mathrm{N}\right)$, mean $25(\mathrm{OH}) \mathrm{D}$ among healthy females was $35.3 \mathrm{nmol} / \mathrm{L}$, and $40.5 \%$ of them had $25(\mathrm{OH}) \mathrm{D}$ values below $25 \mathrm{nmol} / \mathrm{L}$ [35].

High prevalence of hypovitaminosis D in South Asia can be explained by skin pigmentation and traditional clothing. Air pollution and limited outdoor activity further compounds this problem in the urban population.

Vitamin D status of the population in Southeast Asian countries has received relatively less attention. However, the problem seems to be less severe [36, 37]. Most studies used serum $25(\mathrm{OH}) \mathrm{D}$ level of $75 \mathrm{nmol} / \mathrm{L}$ as the cut-off. Prevalence of hypovitaminosis D $(25(\mathrm{OH}) \mathrm{D}<75 \mathrm{nmol} / \mathrm{L})$ in postmenopausal women was $47 \%$ in Thailand, $49 \%$ in Malaysia, $90 \%$ in Japan, and $92 \%$ in South Korea [38]. The mean serum $25(\mathrm{OH}) \mathrm{D}$ concentration was $48 \mathrm{nmol} / \mathrm{L}$ in premenopausal women from Indonesia $\left(6^{\circ} \mathrm{S}\right)$ and Malaysia $\left(2^{\circ} \mathrm{N}\right)$ [39]. In the Oslo immigrant study, prevalence of hypovitaminosis $\mathrm{D}$ was higher in those born in Pakistan and lower in those born in Vietnam compared to the other ethnic groups. Fatty fish intake and cod liver oil supplements were important determinant factors of vitamin D status in the groups studied [40]. One small study in Thailand showed high serum levels of 25(OH)D [37], possibly related to its geographical location close to the equator. Further studies are needed to confirm this. To some extent, these variations can be attributed to the differences in serum $25(\mathrm{OH}) \mathrm{D}$ assay methodology in various studies.

Rickets appears to be common in Mongolia and China $\left(40^{\circ} \mathrm{N}\right)$ [41], and this is probably related both to poor vitamin D status and low calcium intake. In a study from North China (Beijing), $89 \%$ of Chinese adolescent girls had hypovitaminosis D (serum $25(\mathrm{OH}) \mathrm{D}<50 \mathrm{nmol} / \mathrm{L}$ ) [42], and $48 \%$ of old men had severe hypovitaminosis $\mathrm{D} /$ frank vitamin D deficiency $(<25 \mathrm{nmol} / \mathrm{L})$ [43]. Among postmenopausal women, serum $25(\mathrm{OH}) \mathrm{D}$ level was found to be lower amongst the Malays $(44 \pm 11 \mathrm{nmol} / \mathrm{L})$ than the Chinese $(69 \pm 16 \mathrm{nmol} / \mathrm{L})$ [44]. The relatively lower serum 25(OH)D level among Malays can be explained by their skin pigmentation, lower outdoor activity levels, or greater fat mass. In Hong Kong, the mean serum 25(OH)D was $71 \pm 27 \mathrm{nmol} / \mathrm{L}$ in adults over 50 years of age [45], but hypovitaminosis $\mathrm{D}$ was common among elderly patients with fracture neck of femur [46]. In bottle-fed infants of Hong Kong (on vitamin D fortified milk), serum 25(OH)D levels were normal at 18 months [47]. A dual-centred study in China showed that more than $90 \%$ of young women in Beijing and Hong Kong had 25(OH)D levels $\leq 50 \mathrm{nmol} / \mathrm{L}$. However, the mean values were much lower in the north (Beijing) as compared to the south (Hong Kong; 34 versus $9 \mathrm{nmol} / \mathrm{L} ; p<0.001)$ and $40 \%$ compared to $18 \%$ of young women in Beijing and Hong Kong, respectively, had 25 (OH)D levels $\leq 25 \mathrm{nmol} / \mathrm{L}$ [48].

Hypovitaminosis D in Japan $\left(35^{\circ} \mathrm{N}\right)$ is more common in inactive elderly (mean $30 \mathrm{nmol} / \mathrm{L}$ ) and in women younger compared to older than 30 years of age (mean $34 \mathrm{nmol} / \mathrm{L}$ ) [49]. Overall, the vitamin D status in Japan is relatively better in the regions in South Asia and positively related to fish consumption [49-51]. Prevalence of hypovitaminosis D $(<30 \mathrm{nmol} / \mathrm{L})$ in women over 30 years old is only $10.3 \%$ [49] and in active elderly $(25(\mathrm{OH}) \mathrm{D}<75 \mathrm{nmol} / \mathrm{L})$ is below $5 \%$ [50].

This widespread prevalence of vitamin D deficiency/ insufficiency has a deleterious effect on bone mineral homeostasis and peak bone mass achieved and may subsequently reflect as low BMD [20, 42, 47, 52]. Intervention studies with vitamin D supplements are underway in several of these populations.

\section{Europe}

The vitamin D status within different European countries shows a high variation [53]. A serum 25(OH)D lower than 
$25 \mathrm{nmol} / 1$ was found in $2 \%$ to $30 \%$ of adults, but this percentage may increase to $75 \%$ or more in older persons in institutions [4]. Some international studies used one central laboratory, i.e., one radioimmunological method, for all measurements of serum 25(OH)D. The European Action on Nutrition and Health-Survey (EURONUT-SENECA) on independent older persons showed mean serum 25(OH)D levels of 20 to $30 \mathrm{nmol} / \mathrm{l}$ in Southern European centres to 40 to $50 \mathrm{nmol} / 1$ in Northern Europe [54]. The levels usually were higher in men than in women. The strong positive correlation between serum $25(\mathrm{OH}) \mathrm{D}$ and latitude in this survey was rather unexpected because ultraviolet irradiation is more effective in Southern than in Northern European countries. A similar positive correlation $\left(r^{2}=0.42\right)$ between serum $25(\mathrm{OH}) \mathrm{D}$ and latitude was found in the baseline data of the Multiple Outcomes of Raloxifene Evaluation (MORE) study, a clinical trial on the effect of raloxifene in postmenopausal women with osteoporosis, which also used a central laboratory facility [55]. Within countries, the variation in vitamin $\mathrm{D}$ status also is very high. The supplementation en vitamins et mineraux antioxydants (SUVIMAX) study in French adult men and women between 35 and 65 years showed a mean serum 25(OH)D of $43 \mathrm{nmol} / 1$ in the north and $94 \mathrm{nmol} / 1$ in the southwest of France [56]. In this study, the correlation between serum 25 $(\mathrm{OH}) \mathrm{D}$ and latitude was negative as expected. In the Netherlands, the Longitudinal Ageing Study Amsterdam (LASA) showed a serum $25(\mathrm{OH}) \mathrm{D}$ lower than $25 \mathrm{nmol} / 1$ in $8 \%$ of men and $14 \%$ of women, and lower than $50 \mathrm{nmol} / 1$ in $45 \%$ of men and $56 \%$ of the women [57]. Similar data were found in the population-based Hoorn study and the Swiss Monitoring of Trends and Determinants in Cardiovascular Disease (MONICA) project [58, 59]. A study of Swiss nursing homes observed that $90 \%$ of elderly women had serum $25(\mathrm{OH}) \mathrm{D}$ levels below $50 \mathrm{nmol} / 1$ compared to $57 \%$ in non-institutionalised elderly women [60]. Mean serum 25 $(\mathrm{OH}) \mathrm{D}$ was $45 \mathrm{nmol} / \mathrm{l}$ in Italian postmenopausal women, and levels were lower than $25 \mathrm{nmol} / \mathrm{l}$ in about $30 \%$ [61, 62]. Very low levels were also found in Spanish elderly and institutionalised persons [63], confirming the prevalence in Southern Europe of poor vitamin D status in this social group. Mean serum 25(OH)D was about $25 \mathrm{nmol} / 1$ in breastfed children and about $30 \mathrm{nmol} / \mathrm{l}$ in their mothers in Greece [64]. In adolescents in Greece, serum 25(OH)D was lower than $25 \mathrm{nmol} / \mathrm{l}$ in $47 \%$ in winter [65].

Immigrants from Asian countries and asylum seekers carry a high risk for severe vitamin D deficiency [40, 6668]. Serum 25(OH)D was lower than $25 \mathrm{nmol} / 1$ in $40 \%$ of non-Western immigrants in the Netherlands [69]. Pregnant non-Western women even carry a higher risk: a study in midwife practices in The Hague showed a serum 25 $(\mathrm{OH}) \mathrm{D}$ lower than $25 \mathrm{nmol} / 1$ in more than $80 \%$ of Turkish and Moroccan immigrants. Remarkably, 25(OH)
D was below the detection limit in $22 \%$ of the Turkish women [70].

Determinants of vitamin D status explaining the higher serum 25(OH)D in Northern Europe are the high consumption of fatty fish and cod liver oil equivalent to almost $400 \mathrm{IU}$ or $10 \mu \mathrm{g}$ of vitamin D per day [71]. In the Hoorn study in the Netherlands, the determinants of vitamin D status were time spent outdoors, body mass index, the consumption of fatty fish and margarine (fortified with $3 \mathrm{IU}$ per gramme), and the use of vitamin D supplements [58]. Limited time spent outdoors as a predictor of low vitamin D levels was even higher in patients $>65$ years old, according to a Swiss population study [59]. People in Northern Europe may have a more sun-seeking behaviour, combined with a white skin, while people in Southern Europe may avoid the sun and have a more pigmented skin, which, for the same sunlight exposure, results in less vitamin D production in the skin. In the LASA study, serum $25(\mathrm{OH}) \mathrm{D}$ levels below $50 \mathrm{nmol} / 1$ were positively related to physical performance score, a sum of walking test, chair stands, and tandem stand scores [72]. Serum 25(OH)D below $25 \mathrm{nmol} /$ 1 was a predictor of falls in LASA, but the relationship was significant only in those younger than 75 years of age [73]. In a similar way, serum $25(\mathrm{OH}) \mathrm{D}$ below $30 \mathrm{nmol} / \mathrm{l}$ predicted fractures in persons between 65 and 75 years [74]. However, a relationship between vitamin D status and fracture risk was not observed in the European Prospective Investigation into Cancer and Nutrition (EPIC) study [75].

It can be concluded that vitamin D deficiency (serum 25 $(\mathrm{OH}) \mathrm{D}<25 \mathrm{nmol} / \mathrm{l})$ is more common in Southern than in Northern Europe. Risk groups are the elderly (especially the institutionalised and housebound), adolescents, and nonWestern immigrants. Dependent on the required serum 25 $(\mathrm{OH}) \mathrm{D}$ level, either 50 or $75 \mathrm{nmol} / \mathrm{l}$, the percentage of the population with vitamin $\mathrm{D}$ insufficiency is high or very high in most European countries.

\section{Latin America}

In year 2006, the population of Latin America and Caribbean region was 556 million, from diverse ethnic origins. Mean life expectancy is 73 years and, therefore, a significant growth of elderly population is anticipated all over the region. Hip fracture incidence (an average of published data) is $192 / 100,000$ persons aged 50 years and older. Latitudes range from $33^{\circ} \mathrm{N}$ to $55^{\circ} \mathrm{S}$. Dietary habits show ample variations between regions, and a deficient nutritional status is common in the poorer regions [76]. A few studies have addressed the status of vitamin D among small samples of diverse populations, and a review on the subject raises concern about hypovitaminosis D among different population groups in Latin America [77]. 
A study in healthy elderly men and women from different regions of Argentina showed significant differences in mean values of $25(\mathrm{OH}) \mathrm{D}$ between habitants of northern $(52 \mathrm{nmol} / \mathrm{L})$ and southern $(36 \mathrm{nmol} / \mathrm{L})$ provinces. This study showed a cut-off level of $25(\mathrm{OH}) \mathrm{D}$ of $68 \mathrm{nmol} / \mathrm{L}$ at which serum PTH began to increase [78]. Another study in ambulatory women from Buenos Aires showed differences in $25(\mathrm{OH}) \mathrm{D}$ levels in summer $(63 \mathrm{nmol} / \mathrm{L})$ and winter $(53 \mathrm{nmol} / \mathrm{L})$ [79]. Neonates and mothers from the southernmost province had lower $25(\mathrm{OH}) \mathrm{D}$ than those from Buenos Aires [80], and a proposal for a supplementation scheme for children in that province (twice single doses of 100,000 IU ergocalciferol every 3 months during autumn and winter) resulted in a safe recovery of $25(\mathrm{OH})$ D levels [81].

An international epidemiological investigation conducted in postmenopausal women with osteoporosis from Mexico $(n=149)$, Chile $(n=115)$, and Brazil $(n=151)$ found lower values of 25(OH)D in Mexico than in Chile and Brazil [82]. The percentage of persons with inadequate levels of $25(\mathrm{OH}) \mathrm{D}(<75 \mathrm{nmol} / \mathrm{L})$ in the mentioned countries were $67 \%, 50 \%$, and $42 \%$, respectively. A further study of postmenopausal women screened for a clinical trial on osteoporosis from four different cities in Mexico, who were not taking any supplements, showed a very low value of serum 25(OH)D [83]. Prevalence of hypovitaminosis D depended on its defined threshold and varied from $2 \%$, $31 \%, 62 \%$, to $97 \%$ for $25(\mathrm{OH}) \mathrm{D}$ levels below $22.5,27.5$, 50 , and $75 \mathrm{nmol} / \mathrm{L}$, respectively. Finally, another very recent report showed that osteoporotic women from Mexico City taking calcium and vitamin D supplements had higher values $(84 \mathrm{nmol} / \mathrm{L})$ of $25(\mathrm{OH}) \mathrm{D}$ than those not taking any $(64 \mathrm{nmol} / \mathrm{L})$ [84]. Differences found in results from smallscale studies suggest methodological differences in patient selection, including the use or not of vitamin supplements, seasonal variations, and sun exposure habits.

\section{Middle East and Africa}

Despite ample sunshine, the Middle East $\left(15^{\circ}-36^{\circ} \mathrm{N}\right)$ and Africa $\left(35^{\circ} \mathrm{S}-37^{\circ} \mathrm{N}\right)$ register the highest rates of rickets worldwide. This is in large part explained by limited sun exposure due to cultural practises and prolonged breastfeeding without vitamin D supplementation in the Middle East [85], and by dark skin colour and calcium deficiency, rather than vitamin D deficiency, in several countries in Africa [86]. However, both regions also have a high prevalence for hypovitaminosis D.

Hypovitaminosis D is very common in this region and does not spare the paediatric age [87, 88]. A large proportion of adolescent girls, up to $70 \%$ in Iran [89] and $80 \%$ in Saudi Arabia [90], had 25(OH)D levels below
$25 \mathrm{nmol} / \mathrm{L}$. The reported proportions were $32 \%$ in Lebanese girls and between $9 \%$ and $12 \%$ in Lebanese adolescent boys $[91,92]$. Diarrhoea and maternal vitamin D status in infants [93, 94] and gender, clothing style, season, and socioeconomic status in older children were independent risk factors for 25(OH)D levels [89-91, 95]. Several were also predictors for calcium and vitamin D intake [96].

The first study in adults from the region was conducted in university students and elderly from Saudi Arabia and revealed a mean $25(\mathrm{OH}) \mathrm{D}$ level ranging between 10 and $30 \mathrm{nmol} / \mathrm{L}$ [97]. The mean 25(OH)D level was near $25 \mathrm{nmol} / \mathrm{L}$ in Lebanese, Saudi, Emirati, and Iranian women [98-101]. A similar mean was recorded in elderly Lebanese [102]. The proportion of subjects with vitamin D levels below specific cut-offs varied. It was $35 \%$ for a vitamin D level below $25 \mathrm{nmol} / \mathrm{L}$ in a study of elderly subjects from a geriatric hospital in Israel [103]; and between $60 \%$ and $65 \%$ in Lebanon, Jordan, and Iran [98, 104, 105]; and was $48 \%$ for a cut-off less than $37.5 \mathrm{nmol} / \mathrm{L}$ in subjects from Tunisia [106]. In the elderly Lebanese, $37 \%$ of men and $56 \%$ of women had vitamin $\mathrm{D}$ levels below $25 \mathrm{nmol} / \mathrm{L}$. In the similar international study conducted in women with osteoporosis, the highest proportion of hypovitaminosis D was noted in the Middle East [82]. In a study of hip fracture patients and elderly from Israel, up to $80 \%$ of subjects had hypovitaminosis D [107, 108]. Inadequate vitamin D intake, urban dwelling, female gender, wearing the veil, winter season, age, and high parity were independent predictors of low vitamin D levels [99, 104-106, 109, 110].

Neonates born to mothers with low D levels have lower cord vitamin D levels and may be at risk for rickets and other complications [87, 111]. Studies from Saudi Arabia, Kuwait, United Arab Emirates, and Iran reveal that 10-60\% of mothers and $40-80 \%$ of their neonates had undetectable low vitamin D levels $(0-25 \mathrm{nmol} / \mathrm{L})$ at delivery [112-115]. Neonatal outcomes were not detailed in most studies. Higher socioeconomic status, antenatal care, and vitamin D intake were associated with higher vitamin D levels [115].

The negative impact of low vitamin $\mathrm{D}$ on mineral metabolism is illustrated in the inverse relationship between vitamin D and PTH levels noted in Lebanese of all age groups and in Emirati and Iranian women $(R=-0.2-0.25)$ $[101,116,117]$. A positive correlation between $25(\mathrm{OH}) \mathrm{D}$ and spine, but not hip BMD (Z-score) was noted in postmenopausal Iranian women [118]. Similar correlations were noted in elderly Lebanese with spine, hip, and forearm BMD $(R=0.13-0.3)$ but were not present after adjustment for age, height, lean mass, and PTH levels [102], consistent with findings in Iranian women [116]. Neonatal size or bone mass may be affected by maternal vitamin $\mathrm{D}$ status [87]. No effect of maternal vitamin D levels on neonatal birth weight was detected in a sample of 50 mothers- 
neonates from Iran after adjusting for maternal height, age, and parity [112]. Conversely, in a larger sample of 449 women and their newborns from Tehran, neonates of mothers with adequate calcium and vitamin $\mathrm{D}$ intake were $0.9 \mathrm{~cm}$ taller and had a better Apgar at birth [119]. Vitamin $\mathrm{D}$ supplementation for 1 year increased lean mass, bone area, and bone mass in a randomised controlled trial in Lebanese adolescent girls [92].

In summary, vitamin D levels are quite low across age groups in this region. Consistent predictors of low levels are older age, female gender, multi-parity, the winter season, conservative clothing style, low socioeconomic status, and urban living. The negative impact of low vitamin $\mathrm{D}$ levels on indices of mineral bone metabolism and the positive effect of replacement in adolescents are consistent with observations worldwide and support recommendations to optimise vitamin D status.

\section{North America}

In the USA, serum 25(OH)D levels have been assessed in a representative sample of 20,289 non-institutionalised, civilian males and females in the national health and nutrition examination survey (NHANES) over the period of 20022004 [120, 121]. Among males in selected age categories of $1-5,20-49$, and 70 years and older, the prevalence of 25 $(\mathrm{OH}) \mathrm{D}$ levels considered by some to be deficient $(<37.5 \mathrm{nmol} / \mathrm{L})$ were $2 \%, 13 \%$, and $11 \%$, respectively [120]. The proportions of males with levels below $50 \mathrm{nmol} /$ $\mathrm{L}$ for the same age groups were $8 \%, 29 \%$, and $27 \%$, respectively. The proportions with serum $25(\mathrm{OH}) \mathrm{D}$ concentrations below the level considered by many to be optimal for older adults $(<75 \mathrm{nmol} / \mathrm{L})$, for the same age groups, were $50 \%, 73 \%$, and $78 \%$, respectively. Among females, 25(OH)D levels below $37.5 \mathrm{nmol} / \mathrm{L}$ were present in only $3 \%$ of those aged $1-5$ years but more common in young adults aged $20-49$ years $(19 \%)$ and in women aged 70 years and older (16.5\%). Serum 25(OH)D levels below $50 \mathrm{nmol} / \mathrm{L}$ were present in $8.5 \%, 35 \%$, and $34 \%$ of females in the same three age groups, respectively. The proportions with serum $25(\mathrm{OH}) \mathrm{D}$ levels below $75 \mathrm{nmol} / \mathrm{L}$ were $56 \%$, $73 \%$, and $77 \%$ in these age groups, respectively.

Within these $25(\mathrm{OH}) \mathrm{D}$ categories, however, prevalence of low serum $25(\mathrm{OH}) \mathrm{D}$ levels vary dramatically by race/ ethnicity. For example, among males aged 70 years and older, the prevalence of levels below $50 \mathrm{nmol} / \mathrm{L}$ was $23 \%$ for non-Hispanic whites, $45 \%$ for Mexican Americans, and $58 \%$ for non-Hispanic blacks. By age 70 years and older, the prevalence of levels below $75 \mathrm{nmol} / \mathrm{L}$ in these three groups were $76 \%, 88 \%$, and $93 \%$, respectively. Among women, the corresponding prevalence of values below $50 \mathrm{nmol} / \mathrm{L}$ were $28.5 \%, 55 \%$, and $68 \%$ and of values below
$75 \mathrm{nmol} / \mathrm{L}$ were $73 \%, 89 \%$, and $95 \%$, respectively. Information on the other age groups and on the impact of season on $25(\mathrm{OH}) \mathrm{D}$ levels is also available [120].

Comparison of these values with those in the previous NHANES III conducted in 1988-1994 reveals that secular changes in the $25(\mathrm{OH}) \mathrm{D}$ levels have occurred over the last 10 years $[120,122]$. The more recent $25(\mathrm{OH}) \mathrm{D}$ levels are 5-20 nmol/L lower than those in the 1988-1994 survey [122]. After adjustment for the contribution of assay differences, the newer values remain 5-9 nmol/L lower. The lower values, present more frequently in males than in females, have been explained by the combination of an increase in body mass index, a decrease in the consumption of milk, which in the USA is routinely fortified with vitamin $\mathrm{D}$, and more widespread sunscreen use [120, 122].

National survey data are not available for institutionalised individuals and other high-risk groups in the USA, but investigator-initiated studies reveal that $25(\mathrm{OH}) \mathrm{D}$ levels are, as expected, low in those that do not routinely take supplements. For example, in institutionalised elderly not taking vitamin D supplements, 30\% had 25(OH)D levels below $37.5 \mathrm{nmol} / \mathrm{L}$ [123]. In acute hip fracture patients admitted to a hospital in Boston, the mean serum 25(OH) D level was $32 \mathrm{nmol} / \mathrm{L}$, and half of the patients had extreme vitamin D deficiency, defined as $25(\mathrm{OH}) \mathrm{D}$ levels of $30 \mathrm{nmol} / \mathrm{L}$ and lower [124]. Of 1,536 postmenopausal women residing throughout the USA who were taking pharmacotherapy for osteoporosis, $18 \%$ had $25(\mathrm{OH}) \mathrm{D}$ levels below $50 \mathrm{nmol} / \mathrm{L}$ and $52 \%$ had levels below $75 \mathrm{nmol} / \mathrm{L}$ [125].

In summary, despite growing awareness of the multiple health benefits of an adequate vitamin D status, vitamin D insufficiency abounds and is a growing problem in the USA.

Available data indicate that vitamin D concentrations are low in many otherwise healthy Canadian adults, particularly during winter months, and dependent on ethnic origins. An early study of young women (18-35 years of age) in Toronto found that in winter, $21 \%$ of white women, 32 of non-white women (a group which combined First Nations peoples, South Asian, Indo Asian, and East Asian ancestries), and $25 \%$ of black women had serum concentrations below $40 \mathrm{nmol} / \mathrm{L}$ [126].

Seasonal changes were also observed in a population study of 155 residents of long-term care facilities (83 years of age) [127]. Although the study group had limited outdoor exposure, the prevalence of vitamin D deficiency $(25(\mathrm{OH}) \mathrm{D} \leq 25 \mathrm{nmol} / \mathrm{L})$ increased from $9 \%$ in fall to $18 \%$ in winter $(p=0.03)$ and that of vitamin D insufficiency $(25$ $(\mathrm{OH}) \mathrm{D} \leq 40 \mathrm{nmol} / \mathrm{L}$ ) increased from $38 \%$ in fall to $60 \%$ in spring $(p<0.001)$. Patterns of seasonal variation were also examined in a population of healthy men and women living in Western Canada (Calgary) [128]. At the end of the winter 
season, in men and women of mostly European ancestry, $20 \%$ had serum concentrations below $40 \mathrm{nmol} / \mathrm{L}, 39 \%$ had serum concentrations below $50 \mathrm{nmol} / \mathrm{L}$, and $86 \%$ had serum concentrations below $80 \mathrm{nmol} / \mathrm{L}$. Prevalence of low vitamin $\mathrm{D}$ concentrations decreased in the summer to $9 \%$, $14 \%$, and $68 \%$, respectively, which was associated also with travelling to lower latitudes (below $42^{\circ} \mathrm{N}$ ) in that period. However, it should be pointed out that Calgary receives more hours of sunshine per year than any other Canadian city and, therefore, the data may not be generalised to the whole Canadian population.

The Canadian multicentre osteoporosis study, a prospective epidemiology study of 10,000 randomly selected people from across Canada, is in the process of measuring $25(\mathrm{OH}) \mathrm{D}$ levels (among other analytes). These data will shed more light on the vitamin D situation across Canada.

\section{Oceania}

Several investigations have shown low vitamin D levels in a significant proportion of Australians and a large number of at risk groups within the community. In a prospective study evaluating prevalence of vitamin D deficiency in older people in residential aged-care facilities in the northern Sydney area, vitamin D deficiency (serum 25 $(\mathrm{OH}) \mathrm{D}<28 \mathrm{nmol} / \mathrm{L}$ ) was present in $68 \%$ of men and $86 \%$ of women, with a mean serum $25(\mathrm{OH}) \mathrm{D}$ level of $17 \mathrm{nmol} / \mathrm{L}$ [129]. A case series of elderly patients (mean age 81 years) admitted with a hip fracture to Royal Hobart Hospital, Tasmania, found vitamin D deficiency $(<28 \mathrm{nmol} / \mathrm{L})$ in $67 \%$ [130]. Importantly, community-dwelling elderly are at risk as well. A cross-sectional study of older Tasmanian subjects (mean age 79 years) reported $17 \%$ of the community group to be vitamin $\mathrm{D}$ deficient $(<28 \mathrm{nmol} / \mathrm{L})$ [131]. A significant predictor of vitamin D level in this study was poor physical function and activity.

Low vitamin D status has been reported to be highly prevalent among housebound elderly and among ethnic communities, especially Asians, including in Australia, which has a multicultural population. In a cross-sectional study involving elderly living in assisted care and the community in Sydney metropolitan area, elderly people of Middle Eastern origin were found to be at fourfold risk and elderly of Vietnamese origin at threefold risk of vitamin D deficiency (defined as $<25 \mathrm{nmol} / \mathrm{L}$ ) compared to their counterparts of European Caucasian origin [132]. The study included recently arrived young middle-aged Chinese immigrants, of whom $28 \%$ were vitamin D deficient. In a further study evaluating 25(OH)D levels in communitydwelling elderly of Vietnamese and Australian/British origin, levels $<37 \mathrm{nmol} / \mathrm{L}$ were found in $63 \%$ and $37 \%$, respectively [133]. Data from New Zealand are similar, with evidence that vitamin $\mathrm{D}$ deficiency/insufficiency is a growing problem. Serum 25(OH)D levels in New Zealand reveal much more hypovitaminosis D than expected, especially for those of Pacific Islander and Maori origin [134, 135].

Women who wear a veil for cultural reasons have an increased prevalence of vitamin D deficiency. One study of veiled and dark-skinned pregnant women in an antenatal clinic in Melbourne found that the majority $(80 \%)$ were actually vitamin D deficient $(<22.5 \mathrm{nmol})$ [136]. A crosssectional study of a random sample of Muslim women aged 20-65 years living in an urban community in Southwestern Sydney found vitamin D deficiency (defined as $<30 \mathrm{nmol} / \mathrm{L}$ ) in $68 \%$, hyperparathyroidism in $39 \%$, and high bone turnover in $46 \%$ [137].

There is a strong association between disability, sun exposure, and vitamin D status. Greater disability and associated reduced exposure to sun may contribute to the high prevalence of vitamin D insufficiency reported in a population-based MS case sample [138]. Amongst 136 prevalent cases with MS in Tasmania, those individuals with greater disability were more likely to have vitamin $\mathrm{D}$ insufficiency than controls with odds ratio (OR) of 3.07 (95\% confidence interval $(\mathrm{CI}), 1.37-6.90)$ for $25(\mathrm{OH}) \mathrm{D}$ levels $\leq 40 \mathrm{nmol} / \mathrm{L}$. Overall, $34 \%$ of people with MS had 25 $(\mathrm{OH}) \mathrm{D}$ levels $\leq 40 \mathrm{nmol} / \mathrm{L}$ versus $23 \%$ of community controls.

Vitamin D deficiency has re-emerged as a significant paediatric health issue in Australia and New Zealand, with complications including hypocalcaemic seizures, rickets, limb pain, and fracture. A major risk factor for infants is maternal vitamin $\mathrm{D}$ deficiency. A retrospective audit of medical records of children diagnosed with vitamin $\mathrm{D}$ deficiency rickets in Melbourne identified 25(OH)D levels $\leq 25 \mathrm{nmol} / \mathrm{L}$ in $81 \%$ of the mothers [139]. Ninety percent had levels $\leq 40 \mathrm{nmol} / \mathrm{L}$ or less. Fifty-four of the 55 children were born to mothers with ethnocultural risk factors (including veiling) for vitamin D deficiency. A population-based study of pregnant women and their neonates from Southeastern Sydney identified vitamin D deficiency $(25(\mathrm{OH}) \mathrm{D}<25 \mathrm{nmol} / \mathrm{L})$ in $15 \%$ of women and $11 \%$ of neonates [140]. In a study of women presenting to a general practise for antenatal care in Wellington, $87 \%$ had $25(\mathrm{OH}) \mathrm{D}$ levels $<50 \mathrm{nmol} / \mathrm{L}$ and $61 \%<25 \mathrm{nmol} / \mathrm{L}$ [141]. Only $22 \%$ of the women were veiled, and the group included a diverse ethnic population, including African and Middle Eastern as well as Maori, European, and Polynesian women.

Levels of 25(OH)D tend to be lower at the end of winter compared to the end of summer, as exposure to sunlight is the main source of vitamin D. In a cross-sectional study of a population-based, random sample of women aged 20 92 years in Geelong, 25(OH)D levels were less than 
$28 \mathrm{nmol} / \mathrm{L}$ in $7 \%$ overall and $11 \%$ in winter [142]. Levels were less than $50 \mathrm{nmol} / \mathrm{L}$ in $30 \%$ overall and $43 \%$ in winter. A comparison of vitamin D status in people below 60 years of age using data from cross-sectional studies of three regions across Australia confirmed vitamin D insufficiency $(\leq 50 \mathrm{nmol} / \mathrm{L})$ to be common over a wide latitude range [143]. Prevalence of vitamin D insufficiency in women in winter/spring was $41 \%$ in southeast Queensland $\left(27^{\circ} \mathrm{S}\right)$, $37 \%$ in the Geelong region $\left(38^{\circ} \mathrm{S}\right)$, and $67 \%$ in Tasmania $\left(43^{\circ} \mathrm{S}\right)$. Season appeared to be more important than latitude in determining serum $25(\mathrm{OH}) \mathrm{D}$ levels according to this study. Vitamin D deficiency is common among elderly women with a high risk of fracture living in southern New Zealand. This is most marked in the winter months. In a study involving elderly women living independently in Dunedin, 26\% had 25(OH)D levels below the reference range for healthy adults $(\leq 40 \mathrm{nmol} / \mathrm{L})$. In winter, $69 \%$ had levels below the reference range [144]. A cross-sectional study conducted in Auckland also concluded seasonal variation significantly affected the prevalence of vitamin D insufficiency [145-147]. Also, gender differences have been suggested in $25(\mathrm{OH}) \mathrm{D}$ levels, with men having higher levels of $25(\mathrm{OH}) \mathrm{D}$ throughout the year than women, a finding that persisted after adjusting for potential confounding factors. Predicted duration of $25(\mathrm{OH}) \mathrm{D}$ concentrations less than $50 \mathrm{nmol} / \mathrm{L}$ was 250 days per year in women and 165 days per year in men [146]. Levels of $25(\mathrm{OH}) \mathrm{D}$, in men, peaked in early autumn at $103 \mathrm{nmol} / \mathrm{L}$ with a nadir in early spring at $59 \mathrm{nmol} / \mathrm{L}$ [145].

\section{Discussion}

Defining worldwide what constitutes insufficient or deficient levels of vitamin D has long been debated, and there is currently no standard definition of optimal vitamin D status. It is self-evident that changing the threshold (cut-off point) at which hypovitaminosis $\mathrm{D}$ is defined will alter the percentage of people with such condition. Therefore, comparing vitamin D status across different populations will depend on the thresholds set for hypovitaminosis D. It will also depend upon the assays used to measure serum 25 $(\mathrm{OH}) \mathrm{D}$ levels. Regardless, differences between regions are still observed. This review presents six regions of the world (Asia, Europe, Latin America, Middle East/Africa, North America, and Oceania) with various vitamin D status reports depending on age, gender, ethnicity, latitude, clothing, nutrition, skin pigmentation, cultural practises, and living conditions.

Regardless of the definition of vitamin D sufficiency (usually $50 \mathrm{nmol} / \mathrm{L}$ or $75 \mathrm{nmol} / \mathrm{L}$ ), it is apparent that suboptimal 25(OH)D levels are a worldwide phenomenon with hardly any region spared. However, severe hypovitaminosis
D (usually $<25 \mathrm{nmol} / \mathrm{L}$ ) seems to be most common in the Middle East and South Asian regions, despite abundant sunshine and favourable latitude. It is possible that other regions in Asia and Oceania (or even Africa, which remains largely unstudied) may also be similarly affected, but definitive comments cannot be made in absence of more complete data.

Age and gender

Since the discovery of rickets in children and its association to vitamin D deficiency, this disease has been very well controlled in paediatric settings and treated with exposure to UV light and vitamin D supplementation programmes. This report shows, however, that rickets is still a health issue in Asia, Middle East, Africa, and Oceania and in immigrants in Europe. Rickets is still common in neonates whose mothers have low levels of vitamin D and where the sole nutrition of the infant is breast milk. Osteomalacia is a crippling albeit reversible condition, which continues to be common in parts of Asia like the Indian subcontinent [52]. Furthermore, hypovitaminosis D affects all age groups, from the newborn to the elderly, and is dependent on several lifestyle and environmental conditions. In general, the cutaneous production of vitamin $\mathrm{D}_{3}$ declines with age $[148,149]$, and often, the elderly have to be confined indoors for prolonged periods of time, which compounds the problem. Not surprisingly, therefore, elderly have lower circulating $25(\mathrm{OH}) \mathrm{D}$ levels, as compared to the young population from the same regions and with similar skin colour.

Similarly, hypovitaminosis D affects both men and women in all age groups but mainly depends on external factors. However, there is evidence that women have lower levels than men in elderly Europeans $[54,57,58]$, in noninstitutionalised American civilians of various ethnical subgroups [122], in young adolescents in Lebanon [91], and in a yearly study of healthy aged men and women in New Zealand [146]. This difference is noted also in rural and urban populations [28]. Moreover, pregnant women [23, $70,136,140,141]$ and women breast-feeding for long periods of time $[64,85]$ are at higher risk of hypovitaminosis D. Gender differences also occur due to clothing differences where adolescent girls and adult women wearing the veil have lower levels of vitamin D throughout the year compared to their male counterparts $[91,105]$.

Genetic traits and cultural behaviour

Population studies in Europe have shown that immigrants and asylum seekers from Asian, Middle Eastern, or African origins have greater risks of low vitamin D levels [66-70]. Country of origin, genetic traits, and cultural behaviour are 
important factors in determining vitamin D levels. For example, Vietnamese immigrants in Norway were reported to have lower prevalence of hypovitaminosis D compared to Turkish or Pakistani immigrants [40]. In Canada, young women from Asian and to a lesser extent, African origins, showed lower levels of vitamin D compared to whiteCanadian women [126]. In the USA, African Americans, then Mexican Americans, showed more severe vitamin D deficiency compared to non-Hispanic white Americans [122]. Similar results are also found in Australia where in an elderly population, Middle Eastern, then Asian immigrants, had lower vitamin D levels compared to whiteAustralian and European Caucasians [132, 133]. Finally, New Zealanders of Maori and Pacific Island origins were more vitamin D insufficient compared to European, Asian, and Indian origins [134, 135]. These studies indicate that ethnic differences play a role in the circulating levels of serum vitamin D.

The significant variation of hypovitaminosis D prevalence between people of different origin may partly be explained by differences in skin colour and cultural behaviours. Highly pigmented skins with comparable UV light exposure achieve lesser cutaneous formation of vitamin $\mathrm{D}_{3}$, hence, dark-skinned individuals require greater duration of exposure than their light-skinned counterparts to synthesise comparable amounts of vitamin D [150, 151]. Skin pigment is probably a major factor in the very low 25 $(\mathrm{OH}) \mathrm{D}$ levels seen in the Indian subcontinent, despite abundant sunshine $[20,25,28]$. However, more widespread use of sunscreen users in lighter-skinned populations (now also increasingly used by darker-skinned peoples), may also significantly diminish the cutaneous synthesis of vitamin $\mathrm{D}_{3}$ [152].

Cultural behaviour that may explain vitamin $\mathrm{D}$ variations is linked to nutritional and religious differences between people of different origin but living in the same city or country. The consumption of fatty fish and cod liver oil, major sources of dietary sources of vitamin D, were reported to be more common in immigrants from Vietnam and Sri Lanka as compared to Pakistanis [40]. This is further reinforced by Japanese, Dutch, and Norwegian national studies showing the dependence of vitamin D status on consumption of foods rich, or enriched, in vitamin D [49-51, 58, 71]. Ethnic differences in dairy consumption are also reported in African and Asian immigrants in the USA and, in a country where milk is generally fortified with vitamin $\mathrm{D}$, this may contribute in explaining differences in levels of vitamin D. However, the effectiveness of dairy products with low levels of vitamin D fortification in Canada's health programmes is being questioned, as the average serum $25(\mathrm{OH}) \mathrm{D}$ concentrations were reported to be similar to those of Europeans, where products are usually non-fortified [127].
Clothing practises affect the photosynthesis of vitamin $\mathrm{D}_{3}$ from the skin. It is self-evident that the effect of clothing on vitamin D status will be more pronounced in sunny periods, when differences in clothing practises are greater between ethnic populations. The religious practise of the veil (hijab or niqab), covering totally or all except for the face and arms of women, has been demonstrated to be an independent factor of hypovitaminosis D in the Middle East and Africa [91, 98, 99, 106, 109]. In these regions, however, levels of vitamin D may still be low regardless of clothing practises [33, 105]. In South Asia, clothes usually cover much greater proportion of body surface than is the practise in Europe, Americas, and Oceania, even in summer. Sun-seeking behaviour is uncommon in these populations, both because climate is hot for most of the year and because fair skin is associated with beauty in these cultures. In the most southern and warmest parts of Europe, avoiding the heat and sun had a significant role in reducing 25(OH)D levels [54]. Immigrants living in Australia and New Zealand wearing the veil showed strong tendencies towards low level of vitamin D [136, 137].

\section{Latitude and season}

Synthesis of vitamin $\mathrm{D}_{3}$ in the body depends upon solar radiation of the skin. The amount of UV light at a geographical location depends on the length the sun's rays have to travel through the atmosphere, where it is more or less absorbed. Countries at latitudes nearer to the equator receive more sunlight yearly compared to those nearer the poles, which also changes with seasons. The northern and southern hemispheres are tilted towards the sun from April to September and October to March, respectively. Therefore, both latitude and seasons influence the degree of possible solar radiation a population may receive. The literature reports strong evidence that hypovitaminosis D is greater in winter months for all age groups in Asia [25, 26], Europe [69, 72, 82], Latin America [79], Middle East [91], North America [153], and Oceania [142]. However, in very hot countries and where the majority of women wear veils, vitamin D levels were not significantly higher and were even lower in the summer months, as these women avoided the heat and sun by staying indoors [101, 105].

The measured effect of latitude on levels of vitamin D is pronounced. Theoretically, geographical regions closer to the equatorial latitudes should present higher levels of vitamin D photosynthesis due to longer periods of sunlight. Classic studies from North America first showed this clearly many years ago [154, 155]. Asian migrants that moved to northern countries and Canadian summer holiday takers that travelled closer to equatorial latitudes showed a decrease and increase in their vitamin D levels respectively, confirming this relationship [17-19, 128]. Furthermore, in 
Argentina, vitamin D deficiency is significantly lower in populations living in northern regions where mean latitude, temperature, and heliophany (daily hours of solar irradiation) varied from $48^{\circ} \mathrm{S}$ to $27^{\circ} \mathrm{S}, 3.7^{\circ} \mathrm{C}$ to $16.1^{\circ} \mathrm{C}$, and $3.6 \mathrm{~h}$ to $6.3 \mathrm{~h}$ of UV irradiation, respectively [78]. The findings from China, although in different population groups, also indicate much lower $25(\mathrm{OH}) \mathrm{D}$ levels in northern latitudes $[42,45]$. However, a similar Australian study across a latitude range of $27^{\circ} \mathrm{S}$ to $43^{\circ} \mathrm{S}$ showed lesser variations, with latitude explaining only $3.9 \%$ of the differences in 25 $(\mathrm{OH}) \mathrm{D}$ levels [143]. In contrast, in Europe, most southern countries $\left(<40^{\circ} \mathrm{N}\right)$ demonstrated higher prevalence of vitamin $\mathrm{D}$ deficiency in elderly men and women, compared to northern countries $\left(55-60^{\circ} \mathrm{N}\right)[54,55]$ but can be partly explained by the increase of nutritional vitamin $\mathrm{D}$ intake and lighter skin pigmentation of these populations. Direct comparative studies between countries lying above latitudes of $45^{\circ} \mathrm{N}$ or below $45^{\circ} \mathrm{S}$ and those close to the equator are, however, scarce.

\section{Living condition and outdoor activity}

Limiting outdoor activities can further reduce the amount of sun exposure and thus cutaneous vitamin $\mathrm{D}_{3}$ formation, especially in the elderly population. This global report shows that in many studies of elderly population, hospitalised, institutionalised (nursing home or residential care), housebound, and those with greater disabilities have low or lower vitamin D levels compared to healthy adults as they have limited time spent outdoors [44, 46, 55, 58, 63, 124, $132,138,153]$. Urbanisation is also a predictor of low levels of vitamin D in Asia and the Middle East, as both men and women dwell and work most often indoors compared to rural communities [24, 28, 99]. Air pollution in cities further acts as a barrier to UV light [27]. In developing countries, higher social economic status and familial income has been shown to decrease the prevalence of hypovitaminosis D in all age groups, explained as better outdoor school activities in adolescents, superior antenatal care facilities in pregnant women, improved overall nutritional diet, and higher accessibility to vitamin D supplementation in the elderly [76, 90, 91, 115].

\section{Conclusion}

This global report shows the widespread prevalence of hypovitaminosis D in almost every region of the world studied. There is still paucity of data from some parts of Asia and most of Africa. The re-emergence of vitamin D deficiency as a clinical problem in several parts of the world is a major cause of concern. The degree of hypovitaminosis $\mathrm{D}$ varies from region to region. While 25
$(\mathrm{OH}) \mathrm{D}$ levels below $75 \mathrm{nmol} / \mathrm{L}$ are common in most populations, levels below $25 \mathrm{nmol} / \mathrm{L}$ that constitute frank vitamin D deficiency are most commonly seen in populations at risk, in particular, the elderly. In some regions, such as South Asia and Middle East, frank vitamin D deficiency is common in all age groups, from neonates to the elderly.

Risk factors for hypovitaminosis D include older age; female sex; lower latitude; winter season; darker skin pigmentation; factors that determine sunlight exposure, such as clothing and cultural practises; dietary habits; and national policies of vitamin $\mathrm{D}$ fortification. Skin pigment and cultural practises seem to override the effect of other factors, including latitude, as is evidenced by the higher vitamin D levels in Northern as compared to Southern Europe, and the severity of the problem in South Asia and the Middle East. Seasonal variation is also seen in most populations and at all latitudes, unless individuals cover themselves more extensively during summer in very hot climates. Age seems to have a consistent effect too, but the contributions of fortification and diet are variable.

As prevention of osteoporosis becomes more imperative with the global ageing of the population, the role of nonpharmacological treatments will also become increasingly important. Defining categories of vitamin D deficiencies will affect the prevention strategies employed in a clinical setting. These are vitamin D supplementation, increased exposure to UV light (especially sunlight), fortification of food products with vitamin $\mathrm{D}$, and a better dietary intake. Given the proposed definitions of vitamin D sufficiency, it is possible that populations at high risk will have to resort to supplementation to achieve desired 25(OH)D levels.

Acknowledgments The authors wish to thank the scientific contributions made for regional reports: Asia: Dr. Nidhi Malhotra; Middle East and Africa: Ms. Aida Farha, Ms. Rola El-Rassi, and Mr. Ghassan Baliki; Oceania: Drs. Jacqueline R. Center, Sunita Kaur Sandhu, and Paul J. Lee. The Nutrition Working Group of the IOF Committee of Scientific Advisors was supported by the International Osteoporosis Foundation.

Conflicts of interest None.

\section{References}

1. Parfitt AM, Gallagher JC, Heaney RP et al (1982) Vitamin D and bone health in the elderly. Am J Clin Nutr 36:1014-1031

2. Holick M (2002) Vitamin D: the underappreciated D-lightful hormone that is important for skeletal and cellular health. Curr Opin Endocrinol Diabetes Obes 9:87-98

3. Rizzoli R, Bonjour J (2004) Dietary protein and bone health. J Bone Miner Res 19:527

4. Lips P (2001) Vitamin D deficiency and secondary hyperparathyroidism in the elderly: consequences for bone loss and fractures and therapeutic implications. Endocr Rev 22:477-501

5. Holick MF (1999) Evolution, biologic functions, and recommended dietary allowance for vitamin D. In: Holick 
MF (ed) Vitamin D: physiology, molecular biology and clinical applications. Humana Press, Totowa, New Jersey, pp $1-16$

6. Boland R (1986) Role of vitamin D in skeletal muscle function. Endocr Rev 7:434-448

7. Bischoff HA, Stahelin HB, Urscheler N et al (1999) Muscle strength in the elderly: its relation to vitamin D metabolites. Arch Phys Med Rehabil 80:54-58

8. Holick MF (1990) Vitamin D and the skin: photobiology, physiology and therapeutic efficacy for psoriasis. In: Heersche JNM, Kanis JA (eds) Bone and mineral research. Elsevier, Amsterdam, pp 313-366

9. Garland CF, Comstock GW, Garland FC et al (1989) Serum 25-hydroxyvitamin $\mathrm{D}$ and colon cancer -8 year prospective study. Lancet 2:1176-1178

10. Garland FC, Garland CF, Gorham ED, Young JF (1990) Geographic variation in breast cancer mortality in the United States: a hypothesis involving exposure to solar radiation. Prev Med 19:614-622

11. Hernan MA, Olek MJ, Ascherio A (1999) Geographic variation of MS incidence in two prospective studies of US women. Neurology 53:1711-1718

12. Pittas AG, Harris SS, Stark PC, Dawson-Hughes B (2007) The effects of calcium and vitamin D supplementation on blood glucose and markers of inflammation in nondiabetic adults. Diabetes Care 30:980-986

13. Rostand SG (1979) Ultraviolet light may contribute to geographic and racial blood pressure differences. Hypertension $30: 150-156$

14. Jones G, Horst R, Carter G, Makin HLJ (2007) Contemporary diagnosis and treatment of vitamin D-related disorders. J Bone Miner Res 22:V11-V15

15. Lips P, Chapuy MC, Dawson-Hughes B et al (1999) An international comparison of serum 25-Hydroxyvitamin D measurements. Osteoporos Int 9:394-397

16. Dawson-Hughes B, Heaney RP, Holick MF et al (2005) Estimates of optimal vitamin D status. Osteoporos Int 16:713716

17. Arneil GC (1975) Nutritional rickets in children in Glasgow. Proc Nutr Soc 34:101-109

18. Dunnigan MG, Paton JP, Haase S et al (1962) Late rickets and osteomalacia in the Pakistani community in Glasgow. Scott Med J 7:159-167

19. Holmes AM, Enoch BA, Taylor JL, Jones ME (1973) Occult rickets and osteomalacia amongst the Asian immigrant population. Q J Med 42:125-149

20. Arya V, Bhambri R, Godbole MM, Mithal A (2004) Vitamin D status and its relationship with bone mineral density in healthy Asian Indians. Osteoporos Int 15:56-61

21. Vupputuri MR, Goswami R, Gupta N et al (2006) Prevalence and functional significance of 25-hydroxyvitamin D deficiency and vitamin D receptor gene polymorphisms in Asian Indians. Am J Clin Nutr 83:1411-1419

22. Zargar AH, Ahmad S, Masoodi SR et al (2007) Vitamin D status in apparently healthy adults in Kashmir valley of Indian subcontinent. Postgrad Med J 83:713-716

23. Sachan A, Gupta R, Das V et al (2005) High prevalence of vitamin $\mathrm{D}$ deficiency among pregnant women and their newborns in northern India. Am J Clin Nutr 81:1060-1064

24. Puri S, Marwaha RK, Agarwal N et al (2008) Vitamin D status of apparently healthy schoolgirls from two different socioeconomic strata in Delhi: relation to nutrition and lifestyle. Br J Nutr 99:876-882

25. Goswami R, Gupta N, Goswami D et al (2000) Prevalence and significance of low 25-hydroxyvitamin D concentrations in healthy subjects in Delhi. Am J Clin Nutr 72:472-475
26. Malhotra N, Mithal A, Gupta S, Godbole M (2008) Effect of vitamin D supplementation on bone health parameters of healthy young Indian women. Osteoporos Int 19(Suppl 1):S29-S207

27. Agarwal KS, Mughal MZ, Upadhyay P et al (2002) The impact of atmospheric pollution on vitamin $\mathrm{D}$ status of infants and toddlers in Delhi India. Arch Dis Child 87:111-113

28. Harinarayan CV, Ramalakshmi T, Prasad UV et al (2007) High prevalence of low dietary calcium, high phytate consumption, and vitamin D deficiency in healthy south Indians. Am J Clin Nutr 85:1062-1067

29. Harinarayan CV (2005) Prevalence of vitamin D insufficiency in postmenopausal South Indian women. Osteoporos Int 16:397402

30. Harinarayan CV, Ramalakshmi T, Prasad UV, Sudhakar D (2008) Vitamin D status in Andhra Pradesh: a population based study. Indian J Med Res 127:211-218

31. Atiq M, Suria A, Nizami SQ, Ahmed I (1998) Vitamin D status of breastfed Pakistani infants. Acta Paediatr 87:737-740

32. Rashid A, Mohammed T, Stephens WP et al (1983) Vitamin D state of Asians living in Pakistan. Br Med J 286:182-184

33. Islam MZ, Akhtaruzzaman M, Lamberg-Allardt C (2006) Hypovitaminosis D is common in both veiled and nonveiled Bangladeshi women. Asia Pac J Clin Nutr 15:81-87

34. Islam MZ, Lamberg-Allardt C, Karkkainen M et al (2002) Vitamin D deficiency: a concern in premenopausal Bangladeshi women of two socio-economic groups in rural and urban region. Eur J Clin Nutr 56:51-56

35. Rodrigo MD (2007) Peak bone mass measured by phalangeal BMD and its association with nutritional status, socioeconomics status and physical activity: a community based cross sectional study in Galle district, Sri Lanka. In: Extract from PHD thesis (in press)

36. Chailurkit L-O, Rajatanavin R, Teerarungsikul K et al (1996) Serum vitamin $\mathrm{D}$, parathyroid hormone and biochemical markers of bone turnover in normal Thai subjects. J Med Assoc Thai 79:499-504

37. Chan TYK (1997) Differences in vitamin D status and calcium intake: possible explanations for the regional variations in the prevalence of hypercalcemia in tuberculosis. Calcif Tissue Int 60:91-93

38. Lim SK, Kung AWC, Sompongse S et al (2008) Vitamin D inadequacy in postmenopausal women in Eastern Asia. Curr Med Res Opin 24:99-106

39. Green TJ, Skeaff CM, Rockell JE et al (2007) Vitamin D and its association with parathyroid hormone concentrations in women of child-bearing age living in Jakarta and Kuala Lumpur. Eur J Clin Nutr 62(3):373-378

40. Holvik K, Meyer HE, Haug E, Brunvand L (2005) Prevalence and predictors of vitamin D deficiency in five immigrant groups living in Oslo, Norway: the Oslo Immigrant Health Study. Eur J Clin Nutr 59:57-63

41. Fraser DR (2004) Vitamin D-deficiency in Asia. J Steroid Biochem Mol Biol 89-90:491-495

42. Foo LH, Zhang Q, Zhu K et al (2005) Vitamin D status and its relationship with bone mass in healthy adolescent girls in China. Asia Pac J Clin Nutr 14:S40

43. Yan L, Prentice A, Zhang H et al (2000) Vitamin D status and parathyroid hormone concentrations in Chinese women and men from north-east of the People's Republic of China. Eur J Clin Nutr 54:68-72

44. Rahman SA, Yassin Z, Chan SP (2004) Vitamin D status among postmenopausal Malaysian women. Asia Pac J Clin Nutr 13:255260

45. Wat WZM, Leung JYY, Tam S, Kung AWC (2007) Prevalence and impact of vitamin D insufficiency in southern Chinese adults. Ann Nutr Metab 51:59-64 
46. Pun KK, Wong FHW, Wang C et al (1990) Vitamin D status among patients with fractures neck of femur in Hong-Kong. Bone 11:365-368

47. Leung SSF, Lui S, Swaminathan R (1989) Vitamin D status of Hong-Kong Chinese infants. Acta Paediatr Scand 78:303-306

48. Woo J, Lam CWK, Leung JYY et al (2008) Very high rates of vitamin D insufficiency in women of child-bearing age living in Beijing and Hong Kong. Br J Nutr 99:1330-1334

49. Nakamura K, Nashimoto M, Matsuyama S, Yamamoto M (2001) Low serum concentrations of 25 -hydroxyvitamin D in young adult Japanese women: a cross sectional study. Nutrition 17:921925

50. Nakamura K (2006) Vitamin D insufficiency in Japanese populations: from the viewpoint of the prevention of osteoporosis. J Bone Miner Metab 24:1-6

51. Ono Y, Suzuki A, Kotake M et al (2005) Seasonal changes of serum 25-hydroxyvitamin $\mathrm{D}$ and intact parathyroid hormone levels in a normal Japanese population. J Bone Miner Metab 23:147-151

52. Bhambri R, Naik V, Malhotra N et al (2006) Changes in bone mineral density following treatment of osteomalacia. J Clin Densitom 9:120-127

53. Lips P (2007) Vitamin D status and nutrition in Europe and Asia. J Steroid Biochem Mol Biol 103:620-625

54. Vanderwielen RPJ, Lowik MRH, Vandenberg H et al (1995) Serum vitamin D concentrations among elderly people in Europe. Lancet 346:207-210

55. Lips P, Duong T, Oleksik A et al (2001) A global study of vitamin D status and parathyroid function in postmenopausal women with osteoporosis: baseline data from the multiple outcomes of raloxifene evaluation clinical trial. J Clin Endocrinol Metab $86: 1212-1221$

56. Chapuy MC, Preziosi P, Maamer M et al (1997) Prevalence of vitamin $\mathrm{D}$ insufficiency in an adult normal population. Osteoporos Int 7:439-443

57. Snijder MB, van Dam RM, Visser M et al (2005) Adiposity in relation to vitamin $\mathrm{D}$ status and parathyroid hormone levels: a population-based study in older men and women. J Clin Endocrinol Metab 90:4119-4123

58. van Dam RM, Snijder MB, Dekker JM et al (2007) Potentially modifiable determinants of vitamin D status in an older population in the Netherlands: the Hoorn Study. Am J Clin Nutr $85: 755-761$

59. Burnand B, Sloutskis D, Gianoli F et al (1992) Serum 25hydroxyvitamin D: distribution and determinants in the Swiss population. Am J Clin Nutr 56:537-542

60. Krieg MA, Cornuz J, Jacquet AF et al (1998) Influence of anthropometric parameters and biochemical markers of bone metabolism on quantitative ultrasound of bone in the institutionalized elderly. Osteoporos Int 8:115-120

61. Bettica P, Bevilacqua M, Vago T, Norbiato G (1999) High prevalence of hypovitaminosis D among free-living postmenopausal women referred to an osteoporosis outpatient clinic in Northern Italy for initial screening. Osteoporos Int 9:226-229

62. Isaia G, Giorgino R, Rini GB et al (2003) Prevalence of hypovitaminosis D in elderly women in Italy: clinical consequences and risk factors. Osteoporos Int 14:577-582

63. Quesada JM, Jans I, Benito P et al (1989) Vitamin D status of elderly people in Spain. Age Ageing 18:392-397

64. Challa A, Ntourntoufi A, Cholevas V et al (2005) Breastfeeding and vitamin D status in Greece during the first 6 months of life. Eur J Pediatr 164:724-729

65. Lapatsanis D, Moulas A, Cholevas V et al (2005) Vitamin D: a necessity for children and adolescents in Greece. Calcif Tissue Int 77:348-355
66. Preece MA, Oriordan JL, McIntosh WB et al (1973) Vitamin D deficiency among Asian immigrants to Britain. Lancet 1:907910

67. de Torrent de la Jara G, Pecoud A, Favrat B (2004) Lesson of the week-musculoskeletal pain in female asylum seekers and hypovitaminosis D3. Br Med J 32:156-157

68. Meyer HE, Falch JA, Sogaard AJ, Haug E (2004) Vitamin D deficiency and secondary hyperparathyroidism and the association with bone mineral density in persons with Pakistani and Norwegian background living in Oslo, Norway, The Oslo Health Study. Bone 35:412-417

69. van der Meer IM, Boeke AJP, Lips P et al (2008) Fatty fish and supplements are the greatest modifiable contributors to the serum 25-hydroxyvitamin D concentration in a multiethnic population. Clin Endocrinol (Oxf) 68:466-472

70. van der Meer IM, Karamali NS, Boeke AJP et al (2006) High prevalence of vitamin $\mathrm{D}$ deficiency in pregnant non-Western women in The Hague, Netherlands. Am J Clin Nutr 84:350-353

71. Brustad M, Sandanger T, Aksnes L, Lund E (2004) Vitamin D status in a rural population of northern Norway with high fish liver consumption. Public Health Nutr 7:783-789

72. Wicherts IS, van Schoor NM, Boeke AJP et al (2007) Vitamin D status predicts physical performance and its decline in older persons. J Clin Endocrinol Metab 92:2058-2065

73. Snijder MB, van Schoor NM, Pluijm SMF et al (2006) Vitamin $\mathrm{D}$ status in relation to one-year risk of recurrent falling in older men and women. J Clin Endocrinol Metab 91:2980-2985

74. van Schoor NM, Visser M, Pluijm SMF et al (2008) Vitamin D deficiency as a risk factor for osteoporotic fractures. Bone 42:260-266

75. Roddam AW, Neale R, Appleby P et al (2007) Association between plasma 25-hydroxyvitamin D levels and fracture riskThe EPIC-oxford study. Am J Epidemiol 166:1327-1336

76. Morales-Torres J, Gutiérrez-Ureña S, Osteoporosis Committee of Pan-American League of Associations for Rheumatology (2004) The burden of osteoporosis in Latin America. Osteoporos Int 15:625-632

77. Quintana Duque MA, Toro CE, Restrepo JF et al (2007) Vitamina D en America Latina. Rev Metab Óseo Miner 5:403410

78. Oliveri B, Plantalech L, Bagur A et al (2004) High prevalence of vitamin D insufficiency in healthy elderly people living at home in Argentina. Eur J Clin Nutr 58:337-342

79. Fradinger EE, Zanchetta JR (1999) Vitamin D status in women living in Buenos Aires. Medicina (B Aires) 59:449-452

80. Oliveri MB, Mautalen CA, Alonso A et al (1993) Nutritional state of vitamin $\mathrm{D}$ in mothers and neonates in Ushuaia and Buenos-Aires. Medicina (B Aires) 53:315-320

81. Tau C, Ciriani V, Scaiola E, Acuna M (2007) Twice single doses of $100,000 \mathrm{IU}$ of vitamin $\mathrm{D}$ in winter is adequate and safe for prevention of vitamin D deficiency in healthy children from Ushuaia, Tierra Del Fuego, Argentina. J Steroid Biochem Mol Biol 103:651-654

82. Lips P, Hosking D, Lippuner K et al (2006) The prevalence of vitamin $\mathrm{D}$ inadequacy amongst women with osteoporosis: an international epidemiological investigation. J Intern Med 260:245-254

83. Elizondo-Alanís JR, Espinoza-Zamora JR, Zayas-Jaime SJ (2006) Serum levels of vitamin D in healthy postmenopausal women at 4 cities in Mexico. Rev Metab Óseo Miner 4:389398

84. Hernández-Bueno JA, Vázquez-Alanís A, Sánchez-Méndez E, Sobrino-Cossío S (2008) Blood vitamin D levels in Mexican osteoporotic postmenopausal women with or without supplement administration. World congress on the menopause, Madrid, Spain, 19-23 May 2008 
85. Baroncelli G, Bereket A, El Kholy M et al (2008) Rickets in the Middle East: role of environment and genetic predisposition. J Clin Endocrinol Metab 93:1743-1750

86. Pettifor JM (2004) Nutritional rickets: deficiency of vitamin D, calcium, or both? Am J Clin Nutr 80:1725S-1729S

87. Kimball S, Fuleihan GEH, Vieth R (2008) Vitamin D: a growing perspective. Crit Rev Clin Lab Sci 45:339-414

88. El-Hajj Fuleihan G (2009) Vitamin D deficiency in the Middle East and its health consequences. In: Holick MF (ed) Vitamin D: physiology, molecular biology, and clinical applications, 2nd edn. Humana Press, New Jersey

89. Moussavi M, Heidarpour R, Aminorroaya A et al (2005) Prevalence of vitamin D deficiency in Isfahani High School students in 2004. Horm Res 64:144-148

90. Siddiqui AM, Kamfar HZ (2007) Prevalence of vitamin D deficiency rickets in adolescent school girls in Western region, Saudi Arabia. Saudi Med J 28:441-444

91. El-Hajj Fuleihan G, Nabulsi M, Choucair M et al (2001) Hypovitaminosis D in healthy schoolchildren. Pediatrics 107: E53

92. El-Hajj Fuleihan G, Nabulsi M, Tamim H et al (2006) Effect of vitamin D replacement on musculoskeletal parameters in school children: a randomized controlled trial. J Clin Endocrinol Metab 91:405-412

93. Bahijri SM (2001) Serum 25-hydroxy cholecalciferol in infants and preschool children in the Western region of Saudi Arabiaetiological factors. Saudi Med J 22:973-979

94. Dawodu A, Dawson KP, Amirlak I et al (2001) Diet, clothing, sunshine exposure and micronutrient status of Arab infants and young children. Ann Trop Paediatr 21:39-44

95. Dahifar H, Faraji A, Ghorbani A, Yassobi S (2006) Impact of dietary and lifestyle on vitamin D in healthy student girls aged 11-15 years. J Med Invest 53:204-208

96. Salamoun MM, Kizirian AS, Tannous RI et al (2005) Low calcium and vitamin D intake in healthy children and adolescents and their correlates. Eur J Clin Nutr 59:177-184

97. Sedrani SH, Elidrissy A, Elarabi KM (1983) Sunlight and vitamin D status in normal Saudi subjects. Am J Clin Nutr 38:129-132

98. El-Hajj Fuleihan G, Deeb M (1999) Hypovitaminosis in a sunny country. N Engl J Med 340:1840-1841

99. Gannage-Yared MH, Chemali R, Yaacoub N, Halaby G (2000) Hypovitaminosis D in a sunny country: relation to lifestyle and bone markers. J Bone Miner Res 15:1856-1862

100. Ghannam NN, Hammami MM, Bakheet SM, Khan BA (1999) Bone mineral density of the spine and femur in healthy Saudi females: relation to vitamin D status, pregnancy, and lactation. Calcif Tissue Int 65:23-28

101. Saadi HF, Nagelkerke N, Sheela B et al (2006) Predictors and relationships of serum 25 hydroxyvitamin $\mathrm{D}$ concentration with bone turnover markers, bone mineral density, and vitamin D receptor genotype in Emirati women. Bone 39:1136-1143

102. Arabi A, Baddoura R, Awada $\mathrm{H}$ et al (2006) Hypovitaminosis D osteopathy: is it mediated through $\mathrm{PTH}$, lean mass, or is it a direct effect? Bone 39:268-275

103. Goldray D, Mizrahi-Sasson E, Merdler C et al (1989) Vitamin D deficiency in elderly patients in a general hospital. J Am Geriatr Soc 37:589-592

104. Hashemipour S, Larijani B, Adibi H et al (2006) The status of biochemical parameters in varying degrees of vitamin $\mathrm{D}$ deficiency. J Bone Miner Metab 24:213-218

105. Mishal AA (2001) Effects of different dress styles on vitamin D levels in healthy young Jordanian women. Osteoporos Int 12:931-935

106. Meddeb N, Sahli H, Chahed M et al (2005) Vitamin D deficiency in Tunisia. Osteoporos Int 16:180-183
107. Weisman Y (2003) Vitamin D deficiency rickets and osteomalacia in Israel. Isr Med Assoc J 5:289-290

108. Weisman Y, Salama R, Harell A, Edelstein S (1978) Serum 24, 25-dihydroxyvitamin $\mathrm{D}$ and 25-hydroxyvitamin $\mathrm{D}$ concentrations in femoral neck fracture. Br Med J 2:1196-1197

109. El Sonbaty MR, AbdulGhaffar NU (1996) Vitamin D deficiency in veiled Kuwaiti women. Eur J Clin Nutr 50:315-318

110. Mirsaeid Ghazi AA, Rais Zadeh F, Pezeshk P, Azizi F (2004) Seasonal variation of serum 25 hydroxy D3 in residents of Tehran. J Endocrinol Invest 27:676-679

111. Biale Y, Shany S, Levi M et al (1979) Hydroxycholecalciferol levels in Beduin women in labor and in cord blood of their infants. Am J Clin Nutr 32:2380-2382

112. Bassir M, Laborie S, Lapillonne A et al (2001) Vitamin D deficiency in Iranian mothers and their neonates: a pilot study. Acta Paediatr 90:577-579

113. Ainy E, Ghazi AAM, Azizi F (2006) Changes in calcium, 25 $(\mathrm{OH})$ vitamin $\mathrm{D} 3$ and other biochemical factors during pregnancy. J Endocrinol Invest 29:303-307

114. Molla AM, Al Badawi M, Hammoud MS et al (2005) Vitamin D status of mothers and their neonates in Kuwait. Pediatr Int 47:649-652

115. Serenius F, Elidrissy ATH, Dandona P (1984) Vitamin D nutrition in pregnant women at term and in newly born babies in Saudi Arabia. J Clin Pathol 37:444-447

116. Hosseinpanah F, Rambod M, Hossein-Nejad A et al (2008) Association between vitamin $\mathrm{D}$ and bone mineral density in Iranian postmenopausal women. J Bone Miner Metab 26:86-92

117. Vieth R, Fuleihan GE (2005) There is no lower threshold level for parathyroid hormone as 25-hydroxyvitamin D concentrations increase - contraopinion. J Endocrinol Invest 28:183-186

118. Rassouli A, Milanian I, Moslemi-Zadeh M (2001) Determination of serum 25-hydroxyvitamin D-3 levels in early postmenopausal Iranian women: relationship with bone mineral density. Bone 29:428-430

119. Sabour H, Hossein-Nezhad A, Maghbooli Z et al (2006) Relationship between pregnancy outcomes and maternal vitamin D and calcium intake: a cross-sectional study. Gynecol Endocrinol 22:585-589

120. Looker AC, Pfeiffer CM, Lacher DA et al (2008) Serum 25hydroxyvitamin D status of the US population: 1988-1994 compared with 2000-2004. Am J Clin Nutr 88:1519-1527

121. Yetley EA (2008) Assessing the vitamin D status of the US population. Am J Clin Nutr 88:558S-564S

122. Looker AC, Dawson-Hughes B, Calvo MS et al (2002) Serum 25-hydroxyvitamin D status of adolescents and adults in two seasonal subpopulations from NHANES III. Bone 30:771-777

123. Webb AR, Pilbeam C, Hanafin N, Holick MF (1990) An evaluation of the relative contributions of exposure to sunlight and of diet to the circulating concentrations of 25-hydroxyvitamin $\mathrm{D}$ in an elderly nursing home population in Boston. Am J Clin Nutr 51:1075-1081

124. LeBoff MS, Kohlmeier L, Hurwitz S et al (1999) Occult vitamin D deficiency in postmenopausal US women with acute hip fracture. JAMA 281:1505-1511

125. Holick MF, Siris ES, Binkley N et al (2005) Prevalence of vitamin D inadequacy among postmenopausal North American women receiving osteoporosis therapy. J Clin Endocrinol Metab 90:3215-3224

126. Vieth R, Cole DE, Hawker GA et al (2001) Wintertime vitamin $\mathrm{D}$ insufficiency is common in young Canadian women, and their vitamin D intake does not prevent it. Eur J Clin Nutr 55:10911097

127. Liu BA, Gordon M, Labranche JM et al (1997) Seasonal prevalence of vitamin D deficiency in institutionalized older adults. J Am Geriatr Soc 45:598-603 
128. Rucker D, Allan JA, Fick GH, Hanley DA (2002) Vitamin D insufficiency in a population of healthy western Canadians. Can Med Assoc J 166:1517-1524

129. Sambrook PN, Cameron ID, Cumming RG et al (2002) Vitamin $\mathrm{D}$ deficiency is common in frail institutionalised older people in northern Sydney. Med J Aust 176:560-560

130. Inderjeeth CA, Barrett T, Al-Lahham Y et al (2002) Seasonal variation hip fracture and vitamin D levels in Southern Tasmania. N Z Med J 115:183-185

131. Inderjeeth CA, Nicklason F, Al-Lahham Y et al (2000) Vitamin $\mathrm{D}$ deficiency and secondary hyperparathyroidism: clinical and biochemical associations in older non-institutionalised Southern Tasmanians. Aust N Z J Med 30:209-214

132. Brock K, Wilkinson M, Cook R et al (2004) Associations with vitamin D deficiency in "at risk" Australians. J Steroid Biochem Mol Biol 89-90:581-588

133. Brock K, Cant R, Clemson L et al (2007) Effects of diet and exercise on plasma vitamin D $(25(\mathrm{OH}) \mathrm{D})$ levels in Vietnamese immigrant elderly in Sydney, Australia. J Steroid Biochem Mol Biol 103:786-792

134. Rockell JEP, Green TJ, Skeaff CM et al (2005) Season and ethnicity are determinants of serum 25-hydroxyvitamin D concentrations in New Zealand children aged 5-14 y. J Nutr 135:2602-2608

135. Rockell JEP, Skeaff CM, Williams SM, Green TJ (2006) Serum 25-hydroxyvitamin D concentrations of New Zealanders aged 15 years and older. Osteoporos Int 17:1382-1389

136. Grover SR, Morley R (2001) Vitamin D deficiency in veiled or dark-skinned pregnant women. Med J Aust 175:251-252

137. Diamond TH, Levy S, Smith A, Day P (2002) High bone turnover in Muslim women with vitamin D deficiency. Med J Aust 177:139-141

138. van der Mei IAF, Ponsonby AL, Dwyer T et al (2007) Vitamin D levels in people with multiple sclerosis and community controls in Tasmania Australia. J Neurol 254:581-590

139. Nozza JM, Rodda CP (2001) Vitamin D deficiency in mothers of infants with rickets. Med J Aust 175:253-255

140. Bowyer L, Catling-Paull C, Diamond T et al (2008) Vitamin D, parathyroid hormone and calcium levels in pregnant women and their neonates. Clin Endocrinol (Oxf) . doi:10.1111/j.13652265.2008.03316.x

141. Judkins A, Eagleton C (2006) Vitamin D deficiency in pregnant New Zealand women. N Z Med J 119:U2144
142. Pasco JA, Henry MJ, Nicholson GC et al (2001) Vitamin D status of women in the Geelong Osteoporosis Study: association with diet and casual exposure to sunlight. Med J Aust 175:401-405

143. van der Mei IAF, Ponsonby AL, Engelsen O et al (2007) The high prevalence of vitamin D insufficiency across Australian populations is only partly explained by season and latitude. Environ Health Perspect 115:1132-1139

144. McAuley KA, Jones S, LewisBarned NJ et al (1997) Low vitamin D status is common among elderly Dunedin women. N Z Med J 110:275-277

145. Bolland MJ, Grey AB, Ames RW et al (2006) Determinants of vitamin D status in older men living in a subtropical climate. Osteoporos Int 17:1742-1748

146. Bolland MJ, Grey AB, Ames RW et al (2007) The effects of seasonal variation of 25-hydroxyvitamin $\mathrm{D}$ and fat mass on a diagnosis of vitamin D sufficiency. Am J Clin Nutr 86:959-964

147. Lucas JA, Bolland MJ, Grey AB et al (2005) Determinants of vitamin $\mathrm{D}$ status in older women living in a subtropical climate. Osteoporos Int 16:1641-1648

148. Holick MF, Matsuoka LY, Wortsman J (1989) Age, vitamin D, and solar ultraviolent (letter). Lancet 2:1104-1105

149. Maclaughlin J, Holick MF (1985) Aging decreases the capacity of human skin to produce vitamin D3. J Clin Invest 76:15361538

150. Holick MF, Maclaughlin JA, Doppelt SH (1981) Regulation of cutaneous previtamin D3 photosynthesis in man-skin pigment is not an essential regulator. Science 211:590-593

151. Clemens TL, Adams JS, Henderson SL, Holick MF (1982) Increased skin pigmentation reduces the capacity of skin to synthesise vitamin D3. Lancet 1:74-76

152. Matsuoka LY, Wortsman J, Hanifan N, Holick MF (1988) Chronic sunscreen use decreases circulating concentrations of 25-hydroxyvitamin D: preliminary study. Arch Dermatol 1124:1802-1804

153. Thomas MK, Lloyd-Jones DM, Thadhani RI et al (1998) Hypovitaminosis $\mathrm{D}$ in medical inpatients. $\mathrm{N}$ Engl $\mathrm{J}$ Med 338:777-783

154. Webb AR, Kline L, Holick MF (1988) Influence of season and latitude on the cutaneous synthesis of vitamin D3 - exposure to winter sunlight in Boston and Edmonton will promote vitamin D3 synthesis in human skin. J Clin Endocrinol Metab 67:373-378

155. Holick MF (1994) McCollum award lecture-Vitamin D: new horizons for the 21st century. Am J Clin Nutr 60:619-630 